ROCZNIKI TEOLOGICZNE

Tom LXVII, zeszyt $10-2020$

DOI: http://dx.doi.org/10.18290/rt206710-9

OLENA HALIAN

\title{
DEVELOPMENT OF THE AGENCY OF UKRAINIAN CHILDREN - FORCED MIGRANTS: TASKS OF SCHOOL AND FAMILY
}

\begin{abstract}
The article reveals potential influence of educational environment and conditions of family education on manifestation of pupils' own agency in the context of contemporary Ukrainian realities, in particular, forced migration. Agency support is recognized as an important task of ensuring a vital stability of individuals and updating their personal resources, which are aimed not only at adapting to empirical, social, cultural and existential reality in which they live now, but also at their self-development. To achieve this aim the peculiarities of organization of educational environment and system of family education in changed conditions of life realization have been designed.

Importance of providing psychological and pedagogical support for development of the agency of schoolchildren is substantiated. That can be reached by encouraging teachers to use a humanitarian approach in education and creation of children picture the world, where valuemeaningful attitude to multicultural space contributes to personal growth, and to development of individual educational trajectory for them, which makes possible realization of personal potential and needs by pupils in self-development. Parental influence is presented as an important factor for children to gain new experience of self-awareness through indirect approach in education, transfer of positive experience in overcoming difficult life situations, creating a situation of success in socialization of a child. Particular emphasis is made on cooperation of family and educational institution in identification of markers of agency, their manifestation in patterns of behaviour and values of children. The need to formulate a whole value adult attitude to a child's desire to be an agent of change and self-change is emphasized.
\end{abstract}

Key words: agency of a pupil, forced migration; educational environment; principle of pupils' agency; encouraging self-fulfillment.

Translated by Oxana Pavlishak

Olena Halian - Doctor of Pedagogy, Associate Professor, Drohobych Ivan Franko State Pedagogical University; address for correspondence: Grushewskogo str, 4/9, Drohobych, Ukraine, 82100; e-mail: halyane@ukr.net 


\section{INTRODUCTION}

Migration processes, on one hand, are a sign of modernity and result of globalization of society, probably it is the next concept in civilization of mankind. As a consequence, the prospect of effective realization of one's own potential in various spheres of life and the choice, for example, of freelance as a way of self-realization has become possible for a considerable number of people. However, on the other hand, one can observe phenomenon of forced migration, caused by situation of a person's problems, and finding a psychologically and physically comfortable environment for living (and sometimes survival), care for own physical and mental health. Among a wide range of studies on causes of migration and its consequences I highlight one of the aspects of self-activity of people involved in migration processes, namely, supporting manifestation of their agency. Firstly, I consider an important task to ensure the vital stability of an individual in changed environment. Secondly, I emphasize actualization of personal resources, which are aimed not only at adapting to empirical, social, cultural and existential reality in which a person lives now, but also to self-development. It is necessary to revise, define the features of self-realization in accordance with a new life situation, to reach capabilities, abilities and successfully use them in the changed conditions of life realization (O. Halian, T. Gera ${ }^{1}$ ).

Basic for thorough analysis of mental health issues of a person in forced migration is the category of "agency". I consider its content in relation to the ability of a person to update optimally external and internal capabilities, to integrate adequately the current situation with the prospect of an effective self-incarnation of an individual. Meaning of this concept, in my opinion, includes semantic field of individual perception, understanding, acceptance and transformation of the world, life and own self. This field is a personal reserve, an intentional capacity and an immanent ability to realize own potential in natural and cultural life of mankind. The phenomenon of the agency, in my understanding, manifests itself in recognition and realization of a man as a value, author and creator of own personality and life, an agent of creative influence on the environment ("I create the world"). Thus, the sense of self, which is embedded in the formation of personality, provides formation of self-image in a particular moment of existence, as well as in the

${ }^{1}$ O. Halian, T. Gera, "Markery subiektnosti osobystosti v diahnostytsi subiektyvnoi yakosti zhyttia y osobystisnoi samorealizatsii vymushenykh pereselentsiv," Naukovyi visnyk Khersonskoho derzhavnoho universytetu. Seriia Psykholohichni nauky (2017), 2, 1: 69-73. 
past, and in the same time it creates the basis for transformation in foreseeable future.

Reflection of the content of agency in the situation of forced migration has determined the priority of the study of need and ability of people to externalize their own potential and intentional essence in different spheres of life, their involvement in personal self-realization (and not only the expectoration of help, or even worse, the position of victim without wish to change). It seems to me that maintaining, updating and developing agency of a child involved in migration processes is an important pedagogical and psychologically supportive task for ensuring its life sustainability. There is a need to formulate a new social order in the field of public education and upbringing, namely: to provide pupils with an effective life-style of selfestimation, their adaptability to changing living conditions, but not adaptive self-deformation, which causes difficulties in self-realization and may negatively affect their mental health. Family education tasks also take on a new meaning as they relate to a new stage in family life cycle - arrangement of existence space in forced migration, where children are often in situations of uncertainty, feel differently, perceive themselves in changed living conditions, and therefore need support from parents, need tolerant motivation to find adequate ways of asserting among their peers, avoiding dependent relationships in families that exacerbate age and socially predetermined difficulties and moreover individualization and socialization of this category of children is indispensable.

The purpose of this article is to reveal potential impact of educational environment and family education on manifestation of pupils' agency in today's Ukrainian realities, in particular, forced migration. The aforementioned focuses the subject of scientific search on following questions: a) what are the features of organization of educational space, its process aspects involve manifestation of agency of Ukrainian pupils; b) which family relationships, educational influences, patterns of parental attitudes, their settings motivate to cope independently with new conditions of life and what forms of activities with parents contribute to it.

\section{RESEARCH METHODS}

Realization of the tasks set out by the article is ensured by the use of such methods as: a method of theoretical interpretation, directed transformation, 
through which conceptual approaches to development of agency of pupils under conditions of forced migration are represented in two approaches educational environment and life cycle of a family, adapting to new conditions; concretization as a method of substantiation of agency in dimensions of psychological and pedagogical knowledge. Design of organizational features of educational environment and system of family education in changed conditions of life was based on the leading positions of humanistic, humanitarian, axiological and activity approaches.

\section{EDUCATIONAL RESOURCES AND DEVELOPMENT OF THE AGENCY OF UKRAINIAN PUPILS - FORCED MIGRANTS}

Modern pupils live in a complex and contradictory world. Their perceptions of themselves and their place may be in a situation of cognitive dissonance, when educational ideal and image of a successful person whom to be they are encouraged, by teachers, for example, do not correspond with the ideals of the society in which universal values are declared, but their acceptance by everyone depends on situational factors. And school environment does not always provide such conditions of learning and self-education, upbringing, development and self-development of pupils, which will correspond to their intentional abilities and ability to realize their own personal resources, $\left(\mathrm{K}\right.$. Tomaszek ${ }^{2}$ ) be of value for teachers (educators) $\left(\mathrm{K} . \mathrm{Martin}^{3}\right)$, especially under conditions of forced migration. Taking into account the above mentioned, the role of education is increasing. Its influence on socialization and individualization of young generation must be considered "in the context of social changes, which imply, first of all, a change in philosophy of life, philosophy of education, and in particular educational paradigm..." . In addition, the requirements for a personality of a teacher who works in a multicultural environment are being updated. Its mission is complemented by showing and promotion of openness and tolerance, because in modern

\footnotetext{
${ }^{2}$ K. ToMAszeK, "Wielowymiarowość zaangażowania uczniów w aktywności szkolne," Psychologia rozwojowa (2017), 22, 1: 29-45. DOI:10.4467/20843879PR.17.002.6416.

${ }^{3}$ K. MARTIN, Learner-Centered Innovation: Spark Curiosity, Ignite Passion and Unleash Genius (London: IMPress LP, 2018).

${ }^{4}$ N. SKotna, Osoba v rozkolotii tsyvilizatsii: osvita, svitohliad, dii (Lviv: Ukrainski tekhnolohii, 2005), 320.
} 
world there is an increase in tension and confrontation between culturally different interpretations of reality, values and norms (J. Serkowska-Mąka ${ }^{5}$ ).

Although the role of relationships in educational process is emphasized, a teacher and a pupil are individuals with their individual characteristics, subjective manifestations, and their dialogue is full of personal meanings that penetrate into the rules of their cooperation. I wish that knowledge on pupils' agency and possibilities of its development in educational process of school become a special subject of teacher's activity. This approach to the content of education is determined by modern level of science development in general (post-nonclassical methodology of understanding the subject) psychological and pedagogical approaches, in which a person and educational process are regarded as holistic phenomena characterized by nonlinearity of development and reflect the methodology of new ideas. I consider the research of applied issues of organization of psychological and pedagogical support for development of the agency of pupils an important task of psychological science nowadays. Conceptual approaches to realizing children's personality traits, perceiving their self-worth, taking into account their individuality, struggling for self-fulfillment, ${ }^{6}$ expediency of human and scientific context of education have become the subject of scientific search, discussions and updated views on effectiveness of factors of educational changes. ${ }^{7}$ They depict their understanding of importance of engaging pupils in learning and upbringing on their own need for self-activity and in preparing teachers to organize such educational environment where democratic, humanistic values are postulated.

The above outlines the analysis of content and organization of psychological and pedagogical support for the development of the agency of pupils - forced migrants which is based on the implementation of educational process focused on agency. We mean to define the purpose of education in general, psychological and pedagogical influences in particular; guidelines for the organization of an educational process in which a competitive personality is formed, personality that is able to respond adequately to challenges of time, is interested in self-change and is a subject of its own development; the use of educational dialogue to agency of learner's personality; implementa-

\footnotetext{
${ }^{5}$ J. SERKOWSKA-MĄKA, "Szkoła dla Innego. Filozofia i pedagogika dialogu w edukacji międzykulturowej," Studia Paedagogica Ignatiana 2019, 22, 1: 52-72. DOI: 10.12775/SPI.2019.1.003.

${ }^{6}$ Samoproektuvannia osobystosti u dyskursyvnomu prostori, ed. N. Chepelieva (Kyiv: Pedahohichna dumka, 2016).

${ }^{7}$ Diialnisna samorealizatsiia osobystosti v osvitnomu prostori, ed. S. Maksymenko (Kyiv: Vydavnychyi Dim „Slovo”, 2017).
} 
tion of a supportive strategy in pedagogical cooperation that motivates and encourages manifestation of agency. The outlined characteristics are not new to psychological and pedagogical science. However, their implementation is difficult and requires development of not only educational technology, but scientifically sound and practical approaches to its "incorporation" into educational process.

In the context of the outlined, A. Ksenofontova's technology for the development of pupils' agency seems to be impressive. This technology is represented by three levels of realization:

1. Reproductive (concept of a teacher, repetition). This level of relationship is one-sided and does not depend on the individual manifestation of own, unique features of each participant. Relationships are not focused on dialogue and do not imply dialectical development. Pupils' activities at this stage can be characterized as completing a sample task. The level of cognitive interest is local, the activity is reproducible, there is a reproductive approach to solving learning tasks. Pupils meet with difficulties in setting goals and organizing their own activities.

2. Partial search (teacher following concept). The nature of relationships acquires the trait of a two-way focus on search for truth at this level, encourages manifestation of individual personality traits, actualizes the sense of responsibility for the choice and its embodiment regardless of the logic of the given task. This level of cooperation expects that pupils have a need for learning, comprehension of knowledge they have acquired, and a broad cognitive interest dominates. Activity is determined by the problem set. It is usually full of search and performance, and it encourages pupil to search independently.

3. Research (teacher overcoming concept). This level is realized in the context of freedom of creativity and is based on the maximum of overcoming certain boundaries of individual development of participants in educational process. There is an increasing need to discuss and approve proposals in educational dialogue (A. Ksenofontova ${ }^{8}$ ).

There is a real cooperation between a teacher and a pupil, which I consider to be a resource for developing of the agency of pupils - forced migrants. To my opinion, technologically it is provided with training, self-study, mutual training, coaching method.

\footnotetext{
${ }^{8}$ A. Ksenofontova, "Tehnologiya razvitiya subektnoj pozicii uchashegosya," Vestnik Chelyabinskogo gosudarstvennogo pedagogicheskogo universiteta (2016), 7: 77-81.
} 
I believe that positive changes in educational process can be achieved by: verbalizing by pupils of their evaluative and semantic settings in the context of studying the subject material and emotional experience of the collision of their personal meanings with those, which are filled with the content of what is being studied; bringing pupils to the level of solving problems (moral, social, environmental, etc.); comprehension and disclosure of social and personal significance of studied content from standpoint of personal values as their own meanings' forming principles of their life (outlook, meaning of life, self-image). How can you outline the changes? The answer to this question was formulated by V. Klochko. I am impressed by his point view on the enrichment of pedagogical knowledge with the theory and practice of forming valuable and semantic components of human life. The author believed that pedagogy is inherent in stages and tendency of development of pedagogical thought - classicism, non-classicism, post-nonclassicism. And only a change in the form of thinking can introduce into the theory of science those conceptual tendencies that will contribute to its progress. And not only. He insisted on the need to change the prism of vision of educational situation. It is said that education that relies on V. Klochko's view of "reflecting reality" has exhausted all possibilities to remain humane. ${ }^{9}$ He stated sharply enough that no educational model or pedagogical technology based on this paradigm can be humane. This is because in the paradigm of reflection, a person only reproduces "objective reality" in the parameters of objectivity and reality. However, it does not create its own world as a subject activity, as a reality with subjective coordinates (meanings, senses, values), in which a person is given the opportunity to act meaningfully and responsibly. The paradigm of reflection practically does not take into account the role of culture in formation of multidimensional world of a man as a valuable and semantic field, „open space of life”. It imposes the view on the world as a "space for life" which is to be learned, in the way of mastering the experience accumulated by humanity, in particular, knowledge, skills, ways of thinking, etc. which a person must also be able to reproduced. I support the opinion of $\mathrm{V}$. Klochko that humanization of education is possible only if educational models go beyond the concept of reproduction. Reproductive educational technologies are reflection of mentality of the era in which they originated, inherent only in this world perception. However, the internal tendency of development of pedagogical thought leads to the idea of

\footnotetext{
${ }^{9}$ V. KLOCHKo, Samoorganizaciya v psihologicheskih sistemah: problemy stanovleniya mentalnogo prostranstva lichnosti (Tomsk: Tomskij gosudarstvennyj universitet, 2005).
} 
such pedagogy, which task is not to transit knowledge, skills, not "assimilate" meanings and values, but create conditions for formation of "multidimensional world of a man" (V. Klochko ${ }^{10}$ ), "vital ontology" stein). In this context, teaching focused on personality and pedagogy of support have emerged as basis, influenced by the ideas of humanistic psychology (C.R. Rogers ${ }^{12}$ ). However, they did not ensure proper agency. The emergence of "semantic pedagogy" (A. Asmolov ${ }^{13}$ ) determined not the knowledge itself, but the image of the world, the picture of the world, which this knowledge creates. School should make sure that the picture of the world is holistic and meaningful. According to this approach, the paradigm of "reflection" should change the paradigm of "generation." In this situation, it is important to ensure that educational process is organized in humanitarian way. The central point of such pedagogical technology is recognized as human creation, and techniques which involve ability to: a) combine meaning with the sensual experience of pupils, participating in formation of subjective space of life as the basis of their subjective consciousness; b) combine meaning with the subjective space of pupils, transforming subjective world into reality in which they act, understand meaning of their actions and allow them to be responsible for them; c) combine this reality with values, help them to make reality a true reality. Due to value coordinates, the human world becomes the space for realization of opportunities, expression of essence, self-determination and brings a person closer to other people. Humanitarian content of any knowledge implies an emphasis on meaning to be revealed. At the point of meeting of two subjective worlds, two consciousnesses of "author" and "recipient," their "co-experiences," "co-actions," there humanitarian cognitive act appears, in which "recipient" becomes a "co-author" (V. Ilin $\left.{ }^{14}\right)$. Knowledge gained as a set of conclusions with the help of the humanitarian way of thinking is related to the peculiarities of subjects in the way they interpret information about the world, the other person and about themselves. Humanitarian knowledge is the result not only of rational thinking, but also of such ways of thinking as meaning-making, dialogue, experience, imagina-

\footnotetext{
${ }^{10}$ Ibidem.

${ }^{11}$ S. Rubinshtejn, Bytie i soznanie. Chelovek i mir (Sankt-Peterburg: Piter, 2003).

${ }^{12}$ C.R. Rogers, Freedom to Learn for the 80s (Columbus, OH: Charles E. Merrill Publishing Company, 1983).

${ }^{13}$ A. Asmolov, "Ot pedagogiki dressury, znanij, umenij i navykov - k pedagogike variativnogo razvivayushego smyslovogo obrazovaniya," http://asmolovpsy.ru/ru/motives/113 (22.12.2019).

${ }^{14}$ V. ILIN, "Gumanitarnoe znanie v kontekste sovremennoj kultury," Nasha vlast: dela i lica (2012), 5-6(120), http://nashavlast.ru/article_description/135/2120.html (20.12.2019).
} 
tion, intuition, empathic understanding, reflection, etc. Within the humanitarian methodology, it is important to identify personal (and not only external) quantitative learning outcomes that are required for the study of particular people, development of their personal mechanisms without pre-determined boundaries and measures, create conditions for becoming a person, not "shape" them. Humanitarian knowledge, humanitarian ways of thinking as the basis for the formation of personal qualities, personal growth of pupil through the appropriation of humanistic values, are integrators of the content of education, especially for pupils - forced migrants.

Orientation on development of the agency of pupil is related to such concepts as "individual educational route" and "individual educational trajectory." Their focus on taking into account personal context of learning (model of educational process, "path of self-realization," etc.) is obvious. Although some researchers consider also a specific content and knowledge aspect (educational program, curriculum, structure of educational activity, etc.) besides it. However, it is personal approach that is the most promising in the system of competency training, not as a goal, but as a means for self-development. In this connection, attention is paid to the priority of subjective experience of pupils, variability of their experience with the subject content, conduction of self-control and self-estimation in learning process.

What is the content of an individual educational trajectory? Its promotion in all educational fields characterizes personal way of realizing the pupils' potential and provides them with the opportunity to: determine individual content of study of educational subjects, mastering educational program; set goals in studying a specific topic or section; choose types, forms and pace of education; apply those learning methods that are most relevant to their abilities, interests, needs, motivations, opportunities and experience; realize reflectively the obtained results, evaluate and adjust their activities.

Specification of individual educational trajectory reveals choice of topic by a pupil or, for example, a way of thinking (figurative or logical), level of learning (advanced or encyclopedic, selective or extended). At the same time, importance of maintaining logic in developing certain educational competences and basic fundamentals of the subject is taken into account. I mean fixed number of fundamental educational objects and related semantic structures which along with individual educational trajectory ensure that pupils reach comprehensive educational level.

The above mentioned proves that construction of an individual educational trajectory is determined by such principles as principle of individual 
approach to learning; principle of conscious perspective in learning; principle of flexibility in learning; principle of pupil and teacher co-creation; principle of modularity (module of basic education, variant module (provides choice), module of correction (taking into account individual characteristics of pupils), module of organizational and pedagogical support).

Unlike individual educational trajectory, individual educational route is less formalized and concrete. Targets are fundamental in it. In general, I emphasize the following directions of development of an individual educational route as a means for developing agency of pupils: improving quality of mastering educational program with emphasis on maximum activity of a pupil in "appropriation" (learning) of educational information; developing a personal attitude to significance of knowledge, meaning; maximum stimulation of independence, initiative, creativity, freedom and responsibility in the acquisition and creation of knowledge; formation of creative individuality, development of valuable and semantic sphere, axiological competence, own views and beliefs; formation of own style of activity with emphasis on individual features, potential possibilities, abilities and skills, potential agency. Obviously, it can be embodied only if a teacher supports internal determination of pupils' development. Learning organized in such a way serves at the same time as a factor, mechanism and means of self-development. It is also the author of content and form of own self and directs own way and world around. Thus, knowledge becomes subjectively significant, educational activity and pedagogical process become the environment of development and self-development of a pupil.

I associate development of technology of optimal pedagogical cooperation with pupils-forced migrants according to conceptual basis, which I explain as realization of principle of pupils' agency. Here we are talking about an organization of educational process, which provides: a) balance of values for pedagogical communication (contacting) of positions, thoughts, personal experience of everyone, who is involved, and possibility of its acceptance (or rejection); b) orientation on personal significance of knowledge (also a mere process of accepting the reality) for everyone who is the subject of cooperation; c) indispensability, transdiscipline of information, which is the object of cognition; d) process of meaning-making as a pedagogical action (e.g, a cyclical, didactic projection in the activity of a teacher, which presupposes formation of new patterns of thinking); e) dialogue as a way of coexisting in creation knowledge, meaning, value attitude, worldview; f) rational correlation of identity, culture of social responsibility of content, form 
and methods of managing the processes of learning and formation of skills; g) self-motivation for activity and self-motivation; high level of activity and self-reliance in connection with learning tasks, life tasks; intellectual initiative; h) development-promotion assistance; j) rules creation as the ability to embrace, realize and control the limits of one's own freedom and responsibility (O. Halian ${ }^{15}$ ).

The effect of this principle is inseparable from educational environment, because it stimulates value and semantic of self-organization and conscious life realization as subjective essence of a pupil. Therefore, I consider that adequate identity promotion of a personality as a creator of life, free in action, with the possibility of choice, responsible for consequences of own actions are the guidelines of modern education, a meaningful component of program of psychological and pedagogical support for development of the agency of a pupil who is in forced migration.

\section{FAMILY IN FORCED MIGRATION: HOW TO SUPPORT YOUR CHILD'S DESIRE FOR INDEPENDENT ACTIVITY}

The life cycle of a forced migration family is changed. New challenges affect all areas of life. Taking into account these conditions (along with finding ways of survival), it is important to provide each family member with the prospect of own self-realization (past - present - future) and, more promisingly, to enrich time perspective by reflecting events, own opportunities and generating new meanings. This is especially relevant for children whose perceptions of themselves and the world under the influence in changed living conditions are often controversial. These processes must take into account, firstly, existing in family social microenvironment, which provides children involvement in social values and roles, introducing them into difficulties and contradictions of modern world, and secondly, patterns of family upbringing, and thirdly, common for family co-living and coworking circumstances. In the context of forced migration, both dominant family education system and situational factors are decisive. Their manifestation affects feature of activity of children and adolescents, their self-

${ }^{15}$ O. HaLian, "Pryntsyp subiektnosti osobystosti shkoliara u navchalno-vykhovnomu protsesi: teoretychne obgruntuvannia potreby zaprovadzhennia," Visnyk Chernihivskoho natsionalnoho pedahohichnoho universytetu imeni T. H. Shevchenka, Seriia: Pedahohichni nauky (2017), 144: 343-347. 
-perception. In particular, scientists have revealed influence of parental attitudes on detection of adolescent anxiety (K. Olszewski, E. Talik, M. Oleś ${ }^{16}$ ), and adolescents' perceptions of parental influences in terms of life satisfaction (A. Wołpiuk-Ochocińska, M. Marmola ${ }^{17}$ ). I agree that this partially "measures" educational impact of parental patterns of attitudes toward children, and at the same time it can be the basis for optimization of relationships of parents and child.

In this study I address peculiarities of ensuring agency of school-age children, when a new situation of life (forced migration) may badly affect the ability to be an agent of change, to realize oneself in an unstable world, or, conversely, to encourage children and young people to demonstrate behaviour as a protest riot against another, in a situation different from previous experience, empirical, social, cultural, existential, family and life reality. In this context, it is important to take into account the fact that agency is not only manifested, demonstrated, but, above all, experienced by an individual (description in the categories "subject of experience," "subject of development," "subject of meaning").

Taking into account the above mentioned, I draw attention to characteristics of a child's agency, represented by such a term as "personal position." I propose to consider main criteria for its manifestation.

Cognitive and semantic. Understanding of the concept meaning that represent their social and cultural experience. Awareness of moral ideas, moral norms of era, social group. Complex knowledge about motives, ways of activity, its consequences and effectiveness. Understanding social significance of events, ideas, activities, etc., their humanitarian meaning.

Agency and activity-promotion. Ability to identify, compare goals, beliefs, principles, feelings, values, etc. Ability to receive information from various sources (literature, Internet, personal and social experience, etc.), to use them for own decision making, to solve problem tasks. Ability to substantiate conclusions independently, in particular, and from different points of view, in monologue and polylology, „discovering” own ways of using knowledge (for example, creating a blog about own life in new conditions of

\footnotetext{
${ }^{16}$ K. Olszewski, E. Talik, M. Oleś, "Martwienie się młodzieży w okresie dorastania a percepcja postaw rodzicielskich," Psychologia rozwojowa (2016), 21, 3: 89-103. DOI:10.4467/ 20843879pr.16.018.5529.

17 A. WolPiuk-OchocińsKa, M. Marmola, "Percepcja technik wychowawczych rodziców a zadowolenie z życia młodych osób w okresie adolescencji i wczesnej dorosłości," Psychologia rozwojowa (2018), 23, 3: 39-54. DOI:10.4467/20843879pr.18.015.9356.
} 
life realization). Ability to "transmit" value experience, patterns of humane behaviour into social and personal practice.

Personally evaluative. Independent evaluation of events, statements, actions, qualities (own and from environment), based on humanistic value orientations, attitudes. Ability to empathic understanding, willingness to sympathize. Ethical reflection, valuable meaning of self-determination in situations involving value (moral, etc.) choice, prediction of consequences. Use of emotionally-coloured speech attributes, control of negative emotions.

Difficulties in personal self-determination, social activity, behavioural patterns of families with school-age children involved in migration processes can be predicted. Therefore, focusing on self-efficacy, an agency of a child, I am guided by the idea of child's personal desire, to reconcile own behaviour with environmental conditions and own life principles; to be active during interaction with the surrounding reality and in choice of its means; to carry out self-understanding and expression, reflection of valuesemantic self-expression; be a participant in family business; manage personal resources effectively.

Involvement of parents in supporting their children's desire to be able to cope with difficulties independently is linked to their (parents) understanding of the markers of agency (we distinguish among them independence, initiative, creativity, freedom and responsibility). Their monitoring will make it possible for adults to encourage children's independent activity, their ability to overcome difficulties in self-realization, which becomes especially relevant in the context of migration processes.

I emphasize importance of parental psychological education in developing of the agency of their children. Main tasks of cooperation between educational institution and parents are to form a psychological setting on role of parents in development of child's personality, need to use their (parents) pedagogical opportunities to provide necessary assistance to their family. I believe this is the basis for successful self-realization of young family members. To achieve this goal, it is, first of all, necessary to verbalize the markers of agency for parents. Thus, indicators of independence are factors that show independence of a person from objective conditions of life, ability to make independent judgments and actions, ability to act without assistance and guidance. Indicators of initiative are factors that describe a person's ability to inception, ability to take the first step, move, struggle for something, say something, demonstrate a persistent realization of potential, ability to use reserves quickly. Indicators of creativity are factors that indicate ability to produce fundamentally new ideas, to create spiritual and material 
values in an innovative way. Indicator of freedom on one hand is ability of an individual to express the will independently, easily, and on the other hand is the state of being outside oppression, pressure, limitations. Indicators of responsibility are factors that characterize an individual's ability to take responsibility for something, ability to vouch for someone and for themselves.

In the context of the outlined, one can assume compilation of psychological and pedagogical characteristics of a child, who together with their parents are involved in forced migration. Its content defines:

- firstly, indicators of requirements for personal manifestation of a child, adoption / implementation of group rules and unwritten rules of interpersonal interaction, evaluation of markers of the agency as a personal potential; on this basis, recommendations for communication, subcultural socialization of a child are specified;

- secondly, values that differentiate as acceptable and unacceptable (from outside culture) and are initiated by children themselves. It is also important to evaluate values based on markers of the agency according to following scale: autonomy, initiative - executive obedience, creativity - reproduction, freedom - dependence, responsibility - sacrificial external determinism;

- thirdly, behavioural patterns, social and role models, self-regulatory capabilities, orientation of activity on the subject, situation, own self or others.

Monitoring of manifestations of the children's agency, recorded in the proposed characteristic, developed by educators together with parents, opens the prospects to specify psychological support aimed at development of life sustainability, self-efficacy of children and adolescents. Further mastering of psychotechnics of interaction in various situations of family education will help parents to acquire necessary level of psychological, pedagogical and social competence; to learn experience of role-playing self-organization in different situations of family education; get rid of stereotypes in understanding children's behaviour and their own ones; predict situation; it is psychologically expedient to program the process of interaction with a child, based on peculiarity of situation; to make adequate influence, to choose a productive way of interaction with children; to analyze educational situation at post-realization level.

Productivity and effectiveness of interaction depends largely on agency of parents themselves as they gain new social experiences (O. Halian, I. Halian ${ }^{18}$ ). That is why I believe that using active teaching methods (group

${ }^{18}$ O. Halian, I. Halian, "Specyfika pomocy psychologicznej dla rodziców w realizacji skutecznych strategii wychowania rodzinnego," Pedagogika rodziny. Family Pedagogy (2013), 3(4): 203-213. 
and individual consultations, analysis of anonymous situations, corrective role-playing games, etc.) will help parents to develop important competencies for effective interaction. It is about the ability to choose the appropriate way to interact with a child, to take into account effects and risks of using ineffective family education styles that suppress manifestation of agency; empathy; emotional culture; ability to build adequately and use boundaries of family system (spouse, child, parent-child); value attitude to needs and problems of each family member; ability to change the style of communication with children, depending on their age and gender, ability to use appropriate methods of influence that encourage interaction between family members. However, this is only an external component of psychological and pedagogical support of parents. Important is also psychological assistance aimed at personal growth of adult family members, development of their agency and self-efficacy.

\section{CONCLUSIONS}

Children who find themselves in a forced migration situation may find it difficult to adapt to changing living conditions. I consider important to use opportunities of educational environment and to help in optimizing value and meaningful attitudes of parents in developing ability of pupils to be agents of self-realization in their new social, cultural and existential realities.

Appealing to the category of "agency" in this situation helps to determine the goals of psychological and pedagogical support of personal growth of pupils, maintaining their natural desire for self-realization, self-development. Task of educational institution is to create an environment that involves a humanitarian way of thinking (creating meaning), a space for expressing a pupil's own self, bringing a person closer to other people, cultures. Understanding of the world, of own self and others in such a vision opens the prospects for use of human-dimensional pedagogical technologies, where knowledge is not simply transmitted, but is the result of pupil's creation of a value attitude to gain a picture of the world enriched by new experiences. Significant in this context is the development of an individual educational trajectory, which allows realization of personal approach in the system of competency education and is a means of self-development of pupils, their realization of personal potential.

Childhood experiences of migrated people are affected by parental attitudes. Therefore, I emphasize application of their open encouragement of 
self-realization of their children in a new social and cultural reality, choice of an indirect approach to their upbringing, transfer of positive experience in overcoming difficult life situations. This is ensured by involvement of parents in creating a situation of success in socialization of a child, based on the results of observation of the features of self-creation, manifestation of markers of agency. The complementarity of meaningful pedagogical impact of educational institution and family leads to a design of an environment that provides new experiences of self-awareness of children. Parents' preparation for implementation of family education technology in current circumstances is ensured by active teaching methods and their involvement in compiling psychological and pedagogical characteristics of their children's agency manifestations.

\section{BIBLIOGRAPHY}

Asmolov, A. Ot pedagogiki dressury, znanij, umenij i navykov - $k$ pedagogike variativnogo razvivayushego smyslovogo obrazovaniya, http://asmolovpsy.ru/ru/motives/113 (22.01.2020).

Diialnisna samorealizatsiia osobystosti v osvitnomu prostori. Ed. S. Maksymenko. Kyiv: Vydavnychyi Dim „Slovo”, 2017.

HALIAN, O. „Pryntsyp subiektnosti osobystosti shkoliara u navchalno-vykhovnomu protsesi: teoretychne obgruntuvannia potreby zaprovadzhennia." Visnyk Chernihivskoho natsionalnoho pedahohichnoho universytetu imeni T.H. Shevchenka, Seriia: Pedahohichni nauky (2017), 144: 343-347.

HALIAN, O., GERA T. „Markery subiektnosti osobystosti v diahnostytsi subiektyvnoi yakosti zhyttia y osobystisnoi samorealizatsii vymushenykh pereselentsiv." Naukovyi visnyk Khersonskoho derzhavnoho universytetu. Seriia Psykholohichni nauky (2017), 2, 1: 69-73.

Halian, O., Halian, I. "Specyfika pomocy psychologicznej dla rodzicow w realizacji skutecznych strategii wychowania rodzinnego." Pedagogika rodziny. Family Pedagogy (2013), 3(4): 203-213.

ILIN, V. “Gumanitarnoe znanie v kontekste sovremennoj kultury.” Nasha vlast: dela i lica (2012), 5-6(120), http://nashavlast.ru/article_description/135/2120.html (20.01.2020).

KLоснко, V. Samoorganizaciya v psihologicheskih sistemah: problemy stanovleniya mentalnogo prostranstva lichnosti. Tomsk: Tomskij gosudarstvennyj universitet, 2005.

Ksenofontova, A. "Tehnologiya razvitiya subektnoj pozicii uchashegosya." Vestnik Chelyabinskogo gosudarstvennogo pedagogicheskogo universiteta (2016), 7: 77-81.

Martin, K. Learner-Centered Innovation: Spark Curiosity, Ignite Passion and Unleash Genius. London: IMPress, LP, 2018.

OlsZEWSKI, K., TALIK, E., OLEŚ, M. "Martwienie się młodzieży w okresie dorastania a percepcja postaw rodzicielskich.” Psychologia rozwojowa (2016), 21, 3: 89-103. DOI:10.4467/2084 3879pr.16.018.5529.

Rogers, C.R. Freedom to Learn for the 80s. Columbus, OH: Charles E. Merrill Publishing Company, 1983. 
Rubinshtejn, S. Bytie i soznanie. Chelovek i mir. Sankt-Peterburg: Piter, 2003.

Samoproektuvannia osobystosti u dyskursyvnomu prostori. Ed. N. Chepelieva. Kyiv: Pedahohichna dumka, 2016.

SERKOWSKA-MĄKA, J. "Szkoła dla Innego. Filozofia i pedagogika dialogu w edukacji międzykulturowej.” Studia Paedagogica Ignatiana (2019), 22, 1: 52-72. DOI:10.12775/SPI.2019.1.003.

SkotnA, N. Osoba v rozkolotii tsyvilizatsii: osvita, svitohliad, dii. Lviv: Ukrainski tekhnolohii, 2005.

TOMASzEK, K. "Wielowymiarowość zaangażowania uczniów w aktywności szkolne." Psychologia rozwojowa (2017), 22, 1: 29-45. DOI:10.4467/20843879PR.17.002.6416.

WołPIUK-OCHOCIŃSKA, A., MARMOLA, M. "Percepcja technik wychowawczych rodziców a zadowolenie z życia młodych osób w okresie adolescencji i wczesnej dorosłości." Psychologia rozwojowa (2018), 23, 3: 39-54. DOI:10.4467/20843879pr.18.015.9356.

\section{ROZWÓJ PODMIOTOWOŚCI DZIECI UKRAIŃSKICH - PRZYMUSOWYCH MIGRANTÓW: ZADANIA SZKOŁY I RODZINY}

\section{STRESZCZENIE}

Artykuł ujawnia potencjał wpływu środowiska edukacyjnego i warunków wychowania rodzinnego na przejawianie własnej podmiotowości dzieci w kontekście współczesnych realiów ukraińskich, w szczególności migracji przymusowej. Wspieranie podmiotowości jest uznawane za ważne zadanie zapewnienia stabilności życia osoby i aktualizacji jej zasobów osobistych, których celem jest nie tylko dostosowanie się do rzeczywistości empirycznej, społeczno-kulturowej i egzystencjalnej, w której obecnie żyje, ale także jej samorozwoju. W tym celu zaprojektowano specjalną organizację środowiska edukacyjnego i systemu edukacji rodzinnej w zmienionych warunkach funkcjonowania życia.

Uzasadnione jest znaczenie zapewnienia wsparcia psychologicznego i pedagogicznego dla rozwoju podmiotowości uczniów. W tym celu zachęca się nauczycieli do stosowania humanitarnego podejścia do poznania i tworzenia obrazu świata u dziecka, ponieważ ukształtowane wartościowo-semantyczne nastawienie do przestrzeni wielokulturowej przyczynia się do jego osobistego rozwoju. Ponadto ważne jest opracowanie osobistej trajektorii edukacyjnej dla uczniów. Umożliwia to realizację ich osobistego potencjału i potrzeby samorozwoju. Wpływ rodziców jest przedstawiany jako ważny czynnik umożliwiający dzieciom zdobycie nowego doświadczenia samoświadomości. Wynika to $\mathrm{z}$ tego, że rodzice stosują metody pośredniego rodzicielstwa, wykazują pozytywne doświadczenia w przezwyciężaniu trudnych sytuacji życiowych, stwarzają sytuację sukcesu w socjalizacji dziecka. Szczególny nacisk kładzie się na współpracę rodziny i instytucji edukacyjnej w identyfikowaniu markerów podmiotowości, ich przejawów we wzorach zachowań i wartościach dzieci. Podkreśla się potrzebę sformułowania holistycznego i wartościowego stosunku dorosłych do pragnienia dziecka, aby być podmiotem zmiany i samorealizacji.

Słowa kluczowe: podmiotowość ucznia; przymusowa migracja; środowisko edukacyjne; zasada podmiotowości uczniów; zachęcanie do samorealizacji. 